\title{
Identifikasi Habitat Fisik Sungai dan Keberagaman Biotilik Sebagai Indikator Pencemaran Air Sungai Musi Kota Palembang
}

\author{
Inoy Trisnaini ${ }^{1}$, Tri Novia Kumalasari ${ }^{1}$, Feranita Utama $^{1}$ \\ ${ }^{1}$ Fakultas Kesehatan Masyarakat Universitas Sriwijaya \\ Info Artikel : Diterima Juli 2017 ; Disetujui Februari 2018 ; Publikasi April 2018
}

\begin{abstract}
ABSTRAK
Latar belakang: Sungai menjadi salah satu pemasok air terbesar untuk kebutuhan mahluk hidup yang memiliki fungsi penting bagi kehidupan manusia. Sungai Musi merupakan sumberdaya alam yang menjadi salah satu jalur utama perdagangan dan pemasok air terbesar bagi penduduk Sumatera Selatan. Akan tetapi kondisi Sungai Musi telah mengalami perubahan disebabkan padatnya pemukiman dan industri. Aktivitas ini akan berdampak terhadap kondisi fisik sungai serta habitat hewan air yang menghuni perairan. Penelitian ini bertujuan untuk mengidentifikasi habitat fisik sungai serta keberagaman biotilik sebagai indikator pencemaran perairan Sungai Musi Kota Palembang.

Metode: Penilaian pencemaran perairan ditentukan dengan melihat indikator habitat fisik sungai dengan melihat indicator karakteristik substrak dasar sungai yang terdiri dari 6 (enam) parameter dan indikator faktor gangguan kesehatan sungai yang terdiri dari 12 (dua belas) parameter serta keberagaman biotilik sungai melalui biota makro invertebrata, serta menggunakan metode wawancara kepada masyarakat setempat.

Hasil: Hasil penelitian menunjukkan bahwa kualitas air perairan Sungai Musi di Wilayah Sebrang Ulu I dan II berada dalam kondisi buruk, terlihat dari hasil observasi yang menunjukkan bahwa mayoritas (lebih dari 70\%) parameter berada pada indicator buruk (C). Serta hanya ditemukan satu biota air yaitu ikan. Hasil laboratorium menunjukkan nilai TSS di kedua titik melebihi nilai standar normal, sedangkan nilai COD dan BOD masih di bawah nilai standar normal.

Simpulan: Perairan Sungai Musi di Wilayah Sebrang Ulu I dan II, termasuk ke dalam kategori Buruk (C). Hal ini didasarkan hasil pemeriksaan habitat fisik sungai, pemeriksaan hewan biotilik Serta pemeriksaan kadar TSS, BOD dan COD.
\end{abstract}

Kata kunci: pencemaran air; sungai musi; biotilik; habitat fisik sungai.

\section{ABSTRACT}

Title:Identification of the Physical Habitat and Diversity River Biotilikas Indicators of Water Pollution Musi River Palembang

Background: Rivers became one of the largest water supplier for the needs of living things that have important functions for human life. Musi River is a natural resource that is becoming one of the main lines of trade and the largest supplier of water for the residents of South Sumatra. But conditions have changed Musi River caused there are more residential and industrial. This activity will have an impact on the physical condition of the river as well as the habitat of aquatic animals that inhabit the waters. This study aims to identify the physical habitat of the river as well as the diversity biotilik as an indicator of pollution of the waters of the Musi River Palembang.

Method: The assessment of water pollution is determined by observing the indicator of the river's physical habitat by looking at the baseline substrate characteristic indicator consisting of 6 (six) parameters and indicators of river health disturbance factor consisting of 12 (twelve) parameters and biotenic diversity of the river through invertebrate macro biota, using interview methods to the local community.

Result: The results showed that the water quality of the waters of the Musi River in Sebrang Ulu I and II were in poor condition, visible from the observation showed that the majority (over 70\%) the parameters that were in 
bad indicator $(C)$. As well as just founded the water biota was fish. The laboratory result showes the value of TSS in the second point of exceeding the normal standard, while the COD and BOD values were still below the normal standard.

Conclusion: The waters of the Musi River in Sebrang Ulu I and II are included in the Bad category (C). This is based on the results of examination of the river's physical habitat, examination of biotic animals and examination of TSS, BOD and COD levels

Keyword: water pollution;musi river; biotilik; physical habitat of the river

\section{PENDAHULUAN}

Air menutupi sekitar $71 \%$ permukaan bumi yang sebagian besar (97,4\%) asin. Sisanya sekitar 2,586\% berupa air tawar yang tersimpan sebagai es di kutub dan di dalam tanah, dan hanya $0,014 \%$ lainnya yang dapat langsung dimanfaatkan terdapat dalam bentuk uap air, air tanah yang dapat digunakan, sungai dan danau ${ }^{1}$. Sungai menjadi salah satu pemasok air terbesar untuk kebutuhan mahluk hidup yang memiliki fungsi penting bagi kehidupan manusia. Sungai Musi merupakan sumberdaya alam yang menjadi salah satu jalur utama perdagangan dan pemasok air terbesar bagi penduduk Sumatera Selatan. Akan tetapi kondisi Sungai Musi telah mengalami perubahan disebabkan padatnya pemukiman dan industri seperti pengilangan minyak, pabrik pupuk, pengolahan karet alam, kayu lapis dan lain-lain. Beragamnya kegiatan manusia di sepanjang Sungai Musi ini berdampak terhadap kondisi fisik sungai serta habitat hewan air yang menghuni perairan.

Pada bagian hulu aliran Sungai Musi berlokasi industri pupuk urea, limbah cair hasil proses pengolahan dapat saja dibuang ke perairan Sungai Musi, sehingga mempengaruhi kualitas perairan. Selain itu, terdapat pula wilayah permukiman padat di Kota Palembang dengan aliran Sungai Musi yang melalui pemukiman tersebut, dimana aktivitas warga di perairan sungai masih cukup tinggi. Tingginya aktivitas di perairan sungai tentunya juga dapat memberikan pengaruh terhadap kualitas air sungai, bahkan dapat menyebabkan pencemaran air sungai.

Menurut hasil penelitian Eddy, dkk, (2012) Sungai Musi Palembang antara Polokerto sampai Pulau Salah Nama telah tercemar merkuri total. Kadar merkuri total dalam air berkisar 17,250 - 21,750 ppb, sementara itu kadar merkuri total di sedimen antara $1.125-2.521$ ppb. Berdasarkan pemeriksaan laboratorium Dinas Kesehatan Kota Palembang untuk sampel air Sungai Musi Kota Palembang pada tahun 2010 yang dilakukan di sepuluh kelurahan, diperoleh hasil bahwa mutu air di sepuluh titik tersebut sudah tidak memenuhi syarat baik dari hasil pemeriksaan secara fisik, kimia dan bakteriologis ${ }^{2}$.

Pemantauan pencemaran air umumnya digunakan kombinasi komponen fisika, kimia dan biologi. Chahaya (2003) menyatakan bahwa penggunaan komponen fisika dan kimia saja hanya akan memberikan gambaran kualitas lingkungan sesaat dan cenderung memberikan hasil dengan penafsiran dan kisaran yang luas, oleh sebab itu penggunaan komponen biologi juga sangat diperlukan karena fungsinya yang dapat mengantisipasi perubahan pada lingkungan kualitas perairan ${ }^{2}$. Beberapa penelitian telah membuktikan peranan komponen biologi sebagai indikator pencemaran perairan ${ }^{3,4,5,6}$, khususnya yaitu hewan makro invertebrata.

Undang-Undang Air Bersih Nasional (Federal Clean Water Act) telah menetapkan makroinvertebrata sebagai parameter sasaran dan prasyaratan dalam pemantauan keberhasilan pengelolaan kualitas air. Penggunaan hewan makroinvertebrata ini selanjutnya dikenal dengan istilah biotilik, sebagai bentuk pemeriksaan yang dapat memberikan hasil akurat, mudah dilakukan, dan tidak membutuhkan peralatan yang rumit dan mahal. Hal ini menjadi keunggulan utama pemantauan biotilik ${ }^{7}$.

Berdasarkan data Badan Pusat Statistik Kota Palembang Tahun 2010, Sebrang Ulu I dan Sebrang Ulu II merupakan beberapa diantara wilayah di Kota Palembang dengan kepadatan penduduk yang tinggi yaitu masing-masing dengan kepadatan 9.331,65 dan $8.631,99 .^{2}$ Hal ini menunjukkan tingginya aktivitas penduduk di wilayah permukiman tersebut, termasuk aktivitas penduduk di perairan Sungai Musi yang melintasi wilayah tersebut. Selain itu, berdasarkan data dari Badan Lingkungan Hidup Daerah Kota Palembang (2011), bahwa dari hasil pemeriksaan sampel air badan air Sungai Musi di dapatkan kualitas perairan Sungai Musi di wilayah Sebrang Ulu dari indikator bakteriologis, fisika dan kimia kesemuanya berada pada tingkat Tidak Memenuhi Syarat (TMS) berdasarkan Peraturan Gubernur Sumsel No 16 Tahun 2005 Tentang Baku Mutu Air Sungai ${ }^{2,8}$. Maka tujuan dari penelitian ini ialah untuk mengidentifikasi habitat fisik sungai dan keberagaman biotilik Sungai Musi di wilayah perairan Sebrang Ulu I dan II.

\section{MATERI DAN METODE}

Penelitian dilakukan di perairan Sungai Musi di sekitar wilayah Sebrang Ulu I dan II Kota Palembang. Pemeriksaan dilakukan pada 5 titik, masing-masing 3 titik di di wilayah Sebrang Ulu I dan 2 titik di wilayah Sebrang Ulu II. Berdasarkan pertimbangan padatnya penduduk di wilayah tersebut serta diketahui aktivitas penduduk masih banyak dilakukan di daerah bantaran sungai. Penelitian ini merupakan penelitian deskriptif analitik. Penentuan titik pemeriksaan dilakukan secara purposive random sampling dengan kriteria pemilihan titik ialah merupakan wilayah yang padat penduduk 
serta tingginya aktivitas penduduk di wilayah bantaran sungai.

Tabel 1. Kriteria Penentuan Kualitas Habitat Fisik Sungai

\begin{tabular}{ll}
\hline \multicolumn{1}{c}{ Kualitas Habitat } & \multicolumn{1}{c}{ Indikator } \\
\hline Baik (A) & $70 \%$ atau lebih parameter habitat sungai termasuk \\
& dalam kategori Baik (A) \\
Cukup (B) & Selain dari kedua indicator lainnya \\
Buruk (C) & $70 \%$ atau lebih parameter habitat sungai termasuk \\
& dalam kategori Buruk (C) \\
\hline
\end{tabular}

Sumber: Ecoton, 2011.

Penilaian habitat fisik sungai ditentukan dengan melihat indicator karakteristik substrak dasar sungai yang terdiri dari 6 (enam) parameter serta indikator faktor gangguan kesehatan sungai yang terdiri dari 12 (dua belas) parameter. Adapun indikator keberagaman komunitas biotilik perairan sungai dengan melihat biota tidak bertulang belakang dari berbagai grup biotilik mulai dari tingkat sangat sensitif terhadap pencemaran hingga sangat tahan pencemaran ${ }^{7}$. Selain pemeriksaan fisik dan biologis, penelitian juga menggunakan metode wawancara untuk mendukung informasi yang diperoleh terkait kondisi habitat fisik sungai. Wawancara dilakukan pada beberapa warga yang bermukim di sekitar wilayah pemeriksaan. Instrumen yang digunakan dalam penelitian ialah kaca pembesar, lembar pemeriksaan habitat fisik sungai dan lembar pemeriksaan biotilik.

1. Pemeriksaan Habitat Fisik Sungai

Pemeriksaan habitat fisik sungai untuk penilaian kesehatan sungai dilakukan dengan mengikuti prosedur kerja sebagai berikut:

a. Melakukan pengamatan lapangan dengan menyusuri aliran sungai sepanjang 100 meter

b. Parameter habitat fisik sungai diamati

c. Mencatat hasil pengamatan terhadap beberapa parameter habitat sungai dalam Lembar Pemeriksaan Habitat Fisik Sungai (lihat lampiran)

d. Menjumlahkan tanda pada kolom pengamatan dalam kolom kategori.

Berikut ini merupakan kriteria dalam penilaian penentuan kualitas habitat fisik sungai:

a. parameter substrat dasar sungai terdiri dari:

1) Tutupan substrat di zona literal (tepi sungai)

2) Substrat tepi sungai yang terpendam lumpur

3) Pengendapan sedimen
4) Substrat di bagian sungai yang dalam

5) Naungan vegetasi sungai kecil (lebar $<5$ meter)

6) Kekeruhan air sungai

b. Parameter Faktor Gangguan Kesehatan Sungai:

1) Modifikasi aliran sungai

2) Perubahan aliran karena pengerukan atau pelurusan sungai

3) Stabilitas tebing sungai sebelah kiri

4) Stabilitas tebing sungai sebelah kanan

5) Kondisi perlindungan tebing oleh vegetasi bantaran sungai kiri

6) Kondisi perlindungan tebing oleh vegetasi bantaran sungai kanan

7) Lebar vegetasi sempadan sungai sebelah kiri

8) Lebar vegetasi sempadan sungai sebelah kanan

9) Besar fluktuasi tinggi air muka

10) Aktivitas manusia di sekitar sungai dan berapa besar dampaknya

11) Aktivitas manusia pada radius $2 \mathrm{~km}$ di bagian hulu lokasi pengamatan

12) Aktivitas manusia pada radius $2-10 \mathrm{~km}$ di bagian hulu lokasi pengamatan.

2. Pemeriksaan Biotilik

Identifikasi biotilik dilakukan sampai level family dan biotilik dibagi menjadi 4 kelompok berdasarkan daya tahannya terhadap pencemaran air sungai. Kategori biotilik disajikan dalam tabel 2.

3. Wawancara

Wawancara dengan penduduk sekitar untuk mendapatkan informasi mengenai kondisi fisik air sungai Musi di wilayah tersebut dalam keadaan sehari-harinya

Tabel 2. Kategori Biotilik Berdasarkan Daya Tahan Terhadap Pencemaran

\begin{tabular}{llc}
\hline \multicolumn{1}{c}{ Nama } & \multicolumn{1}{c}{ Kategori } & Skor Biotilik \\
\hline Group A & Sangat sensitive & 4 \\
Group B & Sensitive & 3 \\
Group C & Tahan & 2 \\
Group D & Sangat tahan & 1 \\
\hline
\end{tabular}

Sumber: Ecoton, 2011. 
Tabel 3. Penilaian Tingkat Pencemaran Sungai dengan Jumlah Jenis Biotilik dan EPT

\begin{tabular}{lcc}
\hline \multirow{2}{*}{ Tingkat Pencemaran } & \multicolumn{2}{c}{ Indikator } \\
\cline { 2 - 3 } Sungai & Jumlah Jenis Biotilik & Jumlah Jenis EPT \\
\hline Tidak Tercemar & $>13$ & $>7$ \\
Tercemar Ringan & $10-13$ & $3-7$ \\
Tercemar Agak Berat & $7-9$ & $1-2$ \\
Tercemar Sangat Berat & $<7$ & 0 \\
\hline
\end{tabular}

Sumber: Ecoton, 2011.

Tabel 4. Penilaian Kualitas Air dengan Indeks BIOTILIK

\begin{tabular}{cl}
\hline Indeks BIOTILIK & \multicolumn{1}{c}{ Kategori Kualitas Air } \\
\hline $3,1-4,0$ & Sangat bersih, pencemaran sangat ringan \\
$2,6-3,0$ & Bersih, pencemaran ringan \\
$2,1-2,5$ & Agak bersih, pencemaran sedang \\
$1,6-2,0$ & Kotor, pencemaran agak berat \\
$1-1,5$ & Sangat kotor, pencemaran berat
\end{tabular}

Sumber: Ecoton, 2011.

\section{HASIL DAN PEMBAHASAN}

\section{Identifikasi Habitat Fisik Sungai Pada Perairan Sungai Musi di Wilayah Sebrang Ulu I}

Observasi terhadap habitat fisik perairan Sungai Musi dilakukan di tiga titik di wilayah Sebrang Ulu I Kota Palembang.

1. Karakteristik Substrat Dasar Sungai

Berdasarkan hasil observasi di tiga titik pemeriksaan habitat fisik sungai di wilayah Sebrang Ulu I, dinilai bahwa karakteristik substrat dasar sungai berada dalam kondisi kategori Buruk. Sebab berdasarkan hasil skoring terhadap enam parameter, keseluruhan dari parameter pada ketiga titik tersebut memperoleh nilai scoring buruk (C). Maka berdasarkan pemeriksaan habitat fisik sungai menunjukkan bahwa kualitas air perairan Sungai Musi di Wilayah Sebrang Ulu I berada dalam kondisi buruk. Hal ini terlihat dari hasil observasi yang menunjukkan bahwa mayoritas parameter berada pada indikator buruk (C).

Kondisi ini dapat disebabkan oleh tingginya aktivitas masyarakat di sekitar perairan, terutama aktivitas kebutuhan sehari-hari seperti mandi dan mencuci, termasuk masih banyaknya warga yang membuang limbah baik padat maupun cair ke badan air. Hal ini terlihat dari banyaknya limbah padat rumah tangga (domestik) yang menumpuk di pinggiran sungai. Kondisi ini diperparah dengan adanya aktivitas usaha warga yang juga berdampak terhadap kualitas air perairan Sungai Musi di wilayah Sebrang Ulu 1. Diantaranya yaitu aktivitas usaha olahan ikan yang kemudian berdampak disebabkan warga membuang sisa kotoran ikan ke badan air.
2. Faktor Gangguan Kesehatan Sungai

Berdasarkan hasil observasi di tiga titik pemeriksaan habitat fisik sungai di wilayah Sebrang Ulu I, dinilai bahwa faktor gangguan kesehatan sungai berada dalam kondisi kategori Buruk (C). Pada parameter faktor gangguan berdasarkan hasil observasi menunjukkan tingginya aktivitas penduduk di sekitar tiga titik pemeriksaan tersebut, dengan perbedaan aktivitas yaitu, pada titik satu selain pada oleh aktivitas keseharian rumah tangga penduduk, terdapat pula aktivitas dari usaha ikan yang ada di sekitar perairan, berupa kegiatan pencucian, pembersihan kotoran ikan, dimana limbah dari kotoran dan isi perut ikan akan dibuang langsung oleh warga ke perairan sungai. Kondisinya pada saat ini peruntukkan air sungai masih digunakan oleh penduduk untuk kebutuhan sehari-hari seperti mencuci pakai, makanan dan MCK (mandi, cuci kakus).

Adapun pada titik kedua aktivitas keseharian penduduk yang pada ditambah dengan adanya aktivitas pencucian kapal oleh penduduk, yang tentunya akanmemperngaruhi kondisi air sungai. Pada titik tiga terdapat aktivitas usaha pembuatan kapal. Maka secara umum berdasarkan lembar pemeriksaan habitat fisik sungai, baik pada parameter karakteristik substrat dasar sungai maupun faktor gangguan kesehatan sungai, kecenderungan besar menunjukkan kondisi pada kategori Buruk (C). Kondisi ini layaknya kondisisungai-sungai di Surakarta, yaitu Sungai Pepe, Premulung, Anyar dan Jenes, telah tercemar berat ${ }^{9}$.

Maka secara umum berdasarkan lembar pemeriksaan habitat fisik sungai, baik pada parameter karakteristik substrat dasar sungai 
maupun faktor gangguan kesehatan sungai, kecenderungan besar menunjukkan kondisi pada kategori Buruk (C).

\section{Identifikasi Keberagaman Biotilik Pada Perairan Sungai Musi di wilayah Sebrang Ulu I}

Berdasarkan hasil observasi tidak ditemukannya hewan biotilik, baik dari grup A. Sangat sensitif pada pencemaran, grup B. Sensitif pada pencemaran, grup C. Tahan pencemaran, mapun grup D. Sangat tahan pencemaran. Namun pada salah satu lokasi observasi yaitu di titik dua dengan aktivitas penduduk berupa kegiatan sehari-hari rumah tangga dan aktivitas pencucian kapal, ditemukan ikan kecil yang termasuk ke dalam kelompok sangat tahan terhadap pencemaran (D), akan tetapi ikan ditemukan dalam keadaan mati, dengan kondisi perairan sekitar yang dipenuhi buih sabun. Hal ini dapat disebabkan tingginya aktivitas masyarakat yang ada di sekitar perairan, terutama aktivitas pencucian kapal, bagi kehidupan biota air yang ada di sekitarnya, disamping aktivitas mandi oleh penduduk. Kondisi tidak ditemukannya hewan biotilik ini dapat disebabkan aktivitas penduduk di sekitar perairan yang tinggi sehingga mempengaruhi kehidupan biota sungai khususnya biota air yang berukuran kecil. Contoh lainnya ialah Sungai Kampar Kanan di Kota Riau dengan berbagai kegiatan pemanfaatan pada aliran sungai (waduk PLTA Koto Panjang) dan ekstensifikasi dan intensifikasi perkebunan sawit di daerah aliran sungai ditengarai dapat menggeser regim kuantitas dan kualitas air tahunan ekosistim akuatik sungai Kampar. Pencemaran baik berasal dari titik tertentu industri dan pertambangan (point sources) maupun dari sumber tak terpusat (non point sources) berupa bahan organik di sepanjang aliran ${ }^{10}$

Sebagai perbandingan, penelitian lain oleh Wijaya di Bagian Hulu Sungai Cisadane, dengan menggunakan indikator fitoplankton dan perifiton. Berdasarkan klasifikasi dan koefisien saprobik menggunakan parameter biologi (perifiton dan fitoplankton) yang ditemukan menunjukkan pencemaran sungai yang terjadi masih rendah, dengan masukan bahan pencemar berupa bahan organik dan anorganik, namun masih dalam jumlah yang kecil ${ }^{11}$.

\section{Identifikasi Habitat Fisik Sungai Pada Perairan Sungai Musi di Wilayah Sebrang Ulu II}

Observasi terhadap habitat fisik perairan Sungai Musi dilakukan di dua titik di wilayah Sebrang Ulu II Kota Palembang. Pemilihan lokasi didasarkan pada padatnya aktivitas penduduk di sekitar perairan Sungai Musi. Pada pemeriksaan di wilayah Sebrang Ulu II, pemilihan lokasi selain ditentukan berdasarkan tingginya aktivitas sehari-hari seperti mencuci pakaian dan makanan, namun juga berdasarkan tingginya aktivitas industry, mengingat pada wilayah Sebrang Ulu II terdapat dua perusahaan besar, yaitu PT. PUSRI dan PT. Pertamina.
1. Karakteristik Substrat Dasar Sungai

Berdasarkan hasil observasi di dua titik pemeriksaan habitat fisik sungai di wilayah Sebrang Ulu II, dinilai bahwa karakteristik substrat dasar sungai berada dalam kondisi kategori Buruk. Hal ini didasarkan hasil skoring terhadap enam parameter yang keseluruhan parameter pada kedua titik tersebut memperoleh nilai skoring buruk (C). Ke-enam parameter ini terkait substrat sungai yang sebagian besar merupakan sedimen lumpur, serta tidak ditemukannya naungan vegetasi di bantaran sungai.

2. Faktor Gangguan Kesehatan Sungai

Berdasarkan hasil observasi di dua titik pemeriksaan habitat fisik sungai di wilayah Sebrang Ulu II, dinilai bahwa faktor gangguan kesehatan sungai berada dalam kondisi yang bervariasi berdasarkn dua belas parameter yang dilihat. Pada dua titik pemeriksaan yaitu titik 1 ditemukan adanya pelurusan atau pengerukan batu dan pasir sungai, sehingga memperoleh nilai scoring Buruk (C). Sedangkan, pada titik dua memperoleh nilai skoring Baik (A) tidak terdapat aktivitas pengerukan pasir atau batu sungai.

Berdasarkan hasil observasi menunjukkan tingginya aktivitas penduduk di sekitar dua titik pemeriksaan tersebut, dengan perbedaan aktivitas yaitu, pada titik satu selain pada oleh aktivitas keseharian rumah tangga penduduk, terdapat pula aktivitas pengerukan pasir sungai serta pencucian kapal. Pada saat ini peruntukkan air sungai masih digunakan oleh penduduk untuk kebutuhan sehari-hari seperti mencuci pakai, makanan dan MCK (mandi, cuci kakus). Adapun pada titik kedua aktivitas keseharian penduduk yang pada ditambah dengan letaknya yang berdekatan dengan aktivitas industri besar, yang tentunya akanmemperngaruhi kondisi air sungai.

Kondisi ini layaknya kondisi di Sub DAS Anak Sungai Gandong Desa Kerik Takeran. Kemelimpahan gastropoda pada stasiun I rendah disebabkan tidak banyaknya bebatuan untuk menempel, karena gastropoda banyak dijumpai menempel pada bebatuan, atau kayu, tingginya aktifitas manusia seperti pengambilan pasir dan batuan sehingga mempengaruhi kehidupan biota pada stasiun I , memiliki substrat yang berpasir sehingga kurang memiliki bahan organik untuk cadangan makanan bagi gastropoda $^{12}$.

Maka secara umum berdasarkan lembar pemeriksaan habitat fisik sungai, baik pada parameter karakteristik substrat dasar sungai maupun factor gangguan kesehatan sungai, kecenderungan besar menunjukkan kondisi pada kategori Buruk (C).

\section{Identifikasi Keberagaman Biotilik Pada Perairan Sungai Musi di Wilayah Sebrang Ulu II}

Berdasarkan hasil observasi tidak ditemukannya hewan biotilik, baik dari grup A. Sangat sensitive pada pencemaran, grup B. Sensitif pada pencemaran, grup 
C. Tahan pencemaran, mapun grup D. Sangat tahan pencemaran, termasuk ikan yang termasuk ke dalam kelompok sangat tahan terhadap pencemaran (D). Hal ini dapat disebabkan tingginya aktivitas masyarakat yang ada di sekitar perairan, terutama aktivitas pencucian kapal, pengerukan pasir dan batu, termasuk tidak terdapatnya naungan vegetasi yang juga yang merupakan salah satu habitat hewan-hewan indikator biotilik. Termasuk adanya aktivitas industry di sekitr sungai yang dapat saja memberikan pengaruh terhadap kehidupan biota air. Kondisi tidak ditemukannya hewan biotilik ini dapat disebabkan aktivitas penduduk di sekitar perairan yang tinggi sehingga mempengaruhi kehidupan biota sungai khususnya biota air yang berukuran kecil. Namun selain itu kondisi Sungai Musi yang merupakan sungai pasang surut juga bias mempengaruhi keberadaan hewan biotilik.

Adapun penelitian yang dilakukan oleh Leba dkk di Sungai Pajawo Kabupaten Minahasa dengan menggunakan indikator serangga air memperoleh hasil jumlah serangga air yang ditemukan di Sungai Pajowa sebanyak 279 individu yang termasuk dalam 22 dan 14 famili serta 5 ordo. Spesies yang paling banyak ditemukan adalah Gerrisremigisanggota ordo Hemiptera. Kelimpahan dan kekayan serangga air tertinggi ditemukan di bagian tengah aliran sungai dengan kelimpahan spesies 28,00 dan kekayaan spesies 8,50. Kondisi ini menunjukkan masih terjaganya kelestarian di Sungai Pajawo ${ }^{13}$.

\section{Pemeriksaan Parameter TSS, BOD dan COD Pada Perairan Sungai Musi di Wilayah Sebrang Ulu I dan II}

Pemeriksaan parameter TSS, BOD dan COD dilakukan pada dua titik, masing-masing satu titik di wilayah Sebrang Ulu I dan II. Pengambilan dua titik sampel pemeriksaan ini berdasarkan pertimbangan adanya kesamaan karakter kondisi perairan di masingmasing titik yaitu padatnya penduduk serta tingginya aktivitas penduduk di bantaran sungai pada dua wilayah tersebut. Hasil laboratorium menunjukkan bahwa kadar TSS (Total Suspended Solid) pada titik di wilayah Sebrang Ulu I yaitu 48.000, sedangkan di wilayah Sebrang Ulu II yaitu 39.000.

Adapun TSS (Total Suspended Solid) adalah residu dari padatan total yang tertahan oleh saringan dengan ukuran partikel maksimal atau lebih besar dari ukuran partikel koloid. TSS memberikan kontribusi untuk kekeruhan (turbidity) dengan membatasi penetrasi cahaya untuk fotosintesis dan visibilitas di perairan ${ }^{14}$. Kadar 48.000 dan 39.000 pada TSS menunjukkan tingginya tingkat kekeruhan air Sungai Musi di wilayah tersebut, baik di wilayah Sebrang Ulu I maupun Sebrang Ulu II. Kondisi kekeruhan ini dapat dikarenakan karakteristik dari air Sungai Musi itu sendiri yang cenderung keruh jika dilihat secara fisik, namun diperparah dengan tingginya aktivitas warga di sekitar perairan yang kemudian memberikan pengaruh.
Selain itu dilakukan pengukuran parameter BOD pada titik pengambilan sampel, yang diperoleh hasil 4.000 pada pengambilan sampel di wailayahSebrang Ulu I dan 1.000 pada pengambilan sampel di wailayahSebrang Ulu II. Angka ini jelas melebihi nilai batas. Penelitian oleh Agustiningsih dkk di Sungai Blukar Kabupaten Kendal juga memperoleh hasil bahwa dari 7 titik pemeriksaan kesemuanya menunjukkan kadarBOD dan COD yang melebihi baku mutu air sungai Kelas II menurut PP nomor 82 Tahun $2001^{15}$.

BOD (BiologicalOxygenDemand) didefinisikan sebagai banyaknya oksigen yang diperlukan oleh mikroorganisme untuk memecahkan bahan-bahan organik yang terdapat di dalam air. Pemeriksaan BOD diperlukan untuk menentukan beban pencemaran akibat air buangan penduduk atau industri, dan untuk mendesain sistem pengolahan biologis bagi air yang tercemar tersebut. Pemecahan bahan organik diartikan bahwa bahan organik ini digunakan oleh organisme sebagai bahan makanan dan energinya diperoleh dari proses oksidasi ${ }^{16}$. Maka kadar 1.000 dan 4000 pada air Sungai Musi di wilayah tersebut menunjukkan bahwa tingginya zat organik yang terkandungan pada air Sungai Musi di wilayah tersebut, hal ini terutama dapat disebabkan tingginya aktivitas pembuangan limbah organikoleh warga sekitar, baik dari aktivitas sehari-hari seperti buang air besar di sungai, pembuangan kotoran ikan ataupun aktivitas domestic lainnya.

Kadar COD diperoleh sebesar 6.000 di wilayah Sebrang Ulu I serta 3.000 di wilayah Sebrang Ulu II. Angka 3.000 dan 6.000 pada sampel air yang dilakukan pemeriksaan menunjukkan tingginya kandungan bahan kimia yang mencemari air di perairan tersebut. COD atau kebutuhan oksigen kimia (KOK) adalah jumlah oksigen yang dibutuhkan untuk mengoksidasi zat-zat organik yang ada dalam satu liter sampel air. Angka COD merupakan ukuran bagi pencemaran air oleh zat- zat organik yang secara alamiah dapat dioksidasikan melalui proses mikrobiologis, dan mengakibatkan berkurangnya oksigen terlarut di dalam air ${ }^{14}$. Maka angka 3.000 dan 6.000 pada sampel air yang dilakukan pemeriksaan menunjukkan tingginya kandungan bahan kimia yang mencemari air di perairan tersebut. Adapun pada kondisi air di perairan Sungai Musi di wilayah Sebrang Ulu I dan II dapat disebabkan tingginya aktivitas warga sekitar yang dapat menyumbangkan bahan kimia pada badan air, diantaranya yaitu aktivitas mandi dan mencuci sehari-hari yang tentunya menggunakan bahan kimia sebagai bahan pembersih, termasuk adanya aktivitas pencucian kapal di wilayah tersebut, serta aktivitas industry. Sehingga berdampak pada tingginya angka COD. Kondisi TSS, BOD serta COD yang menunjukkan kadar tinggi juga akan terpengaruh terhadap kehidupan hewan di perairan tersebut. 


\section{Menilai Status Pencemaran Sungai Musi di wilayah Sebrang Ulu I dan II}

Berdasarkan hasil pemeriksaan, baik pemeriksaan habitat fisik sungai maupun keberagaman hewan biotilik, serta didukung dengan hasil pemeriksaan laboratorium terhadap kadar TSS, BOD dan COD. Maka secara umum dapat menyimpulkan penilaian kondisi perairan Sungai Musi di lokasi tersebut, termasuk ke dalam kategori Buruk (C). Kemudian pemeriksaan hewan biotilik menunjukkan tidak ditemukannya hewan-hewan tersebut yang merupakan salah satu indikator pencemaran sungai. Serta pemeriksaan kadar TSS, BOD dan COD yang menunjukkan angka yang tinggi.

Kondisi ini layaknya kualitas air sungai dan situ di DKI Jakarta. Berdasarkan penelitian oleh Hendarwan bahwa hasil perhitungan terhadap nilai Indeks Kualitas Air menunjukkan bahwa $83 \%$ sungai dan $79 \%$ SITU yang ada di DKI Jakarta ada dalam kategori buruk. Hal ini disebabkan tidak terpeliharanya sungai dan SITU dengan baik, kurangnya kesadaran masyarakat dan pemerintah dalam upaya memelihara sungai dan SITU ${ }^{17}$.

Kondisi ini tentunya memerlukan tindakan dan strategi pengendalian pencemaran air. Pengendalian pencemaran adalah upaya untuk memaksimumkan dampak positif dan meminimumkan dampak negatif. Optimalisasi semacam ini sangat dipengaruhi oleh faktor politis, sosial dan budaya. Menurut Ginting dalam Hendrawan, usaha pengendalian dan pencegahan pencemaran lingkungan dapat dilakukan melalui berbagai cara seperti: teknologi pencegahan dan penanggulangan, pendekatan institusional, pendekatan ekonomi, pengelolaan lingkungan ${ }^{17}$.

Adapun strategi ini merupakan upaya yang dilakukan dalam rangka pencegahan dan penanggulangan terjadinya pencemaran air serta pemulihan kualitas air sesuai kondisi alaminya sehingga kualitas air sungai terjaga sesuai dengan peruntukkannya. Strategi pengendalian pencemaran air memerlukan serangkaian kriteria dan alternative untuk mencapai tujuan yang diinginkan sesuai dengan kondisi dan kemampuan sumber daya yang ada. Serta pentingnya kerja sama semua pihak dalam hal ini ialah masyarakat umum, industry dan pemerintah ${ }^{18}$.

\section{SIMPULAN}

1. Kualitas perairan Sungai Musi di Wilayah Sebrang Ulu I dan II berdasarkan pemeriksaan habitat fisik sungai, baik pada parameter karakteristik substrat dasar sungai maupun faktor gangguan kesehatan sungai, kecenderungan besar menunjukkan kondisi pada kategori Buruk (C).

2. Berdasarkan hasil observasi tidak ditemukannya hewan biotilik, baik dari grup A (sangat sensitif pada pencemaran), grup B (sensitif pada pencemaran), grup $\mathrm{C}$ (tahan pencemaran), mapun grup D (sangat tahan pencemaran).

3. Hasil laboratorium menunjukkan bahwa kadar TSS (Total Suspended Solid) pada titik di wilayah
Sebrang Ulu I yaitu 48,000 mg/l, dan 39,000 mg/l di wilayah Sebrang Ulu II. Pemeriksaan BOD diperoleh hasil 4,000 mg/l di wilayah Sebrang Ulu I dan $1,000 \mathrm{mg} / 1$ di wilayah Sebrang Ulu II. Kadar COD diperoleh 6,000 mg/l di wilayah Sebrang Ulu I serta 3,000 mg/l di wilayah Sebrang Ulu II

4. Berdasarkan hasil pemeriksaan, baik pemeriksaan habitat fisik sungai maupun keberagaman hewan biotilik, dan hasil pemeriksaan laboratorium terhadap kadar TSS. Maka secara umum dapat menyimpulkan penilaian kondisi perairan Sungai Musi di Sebrang Ulu I dan II, termasuk ke dalam kategori Buruk (C).

\section{DAFTAR PUSTAKA}

1. Soegianto, Agus. Ilmu Lingkungan Sarana Menuju Masyarakat Berkelanjutan. Surabaya :Airlangga University Press; 2010.

2. Sianturi, Tantri Nova. Eksternalitas Negatif dari Pencemaran Sungai Musi-Palembang Terhadap Masyarakat Akibat Kegiatan Industri. Skripsi. Departemen Ekonomi Sumberdaya dan Lingkungan Fakultas Ekonomi dan Manajemen Institut Pertanian Bogor; 2012.

3. Martima,Rifgah, Ratna Siahaan, Roni Koneri dan Marnix L. Langoy. Makrozoobentos Sebagai Indikator Biologis Dalam Menentukan Kualitas Air Sungai Ranoyapo, Minahasa Selatan, Sulawesi Utara. Jurnal Ilmiah Sains. 2013 [diakses 1 Agustus 2015]; Vol. 13 No. 1, April 2013.

4. Salam, Apdus. Analisis Kualitas Air Situ Bungur Ciputat Sebagai Indeks Keanekaragaman Fitoplankton. Sikripsi. Fakultas Sains dan Teknologi Universitas Islam Negeri Syarif Hidayatullah; 2010.

5. Hilda Zulkifli, ZaziliHanafiah dan Dian Asih Puspitawati. Struktur dan Fungsi Komunitas Makrozoobenthos di Perairan Sungai Musi Kota Palembang : Telaah Indikator Pencemaran Air. Prosiding Seminar Nasional Biologi "Meningkatkan Peran Biologi dalam Mewujudkayn National Achievement with Global Reach"; 2009.

6. Hilda Zulkifli, Husnah, Moh. Ridho, dan SuhodoJuanda. Status Kualitas Sungai Musi Bagian Hilir Ditinjau dari Komunitas Fitoplankton. Jurnal Penelitian Hayati. 2009 [diakses 1 Agustus 2015]; 15 (5-9), 2009.

7. Ecoton. Panduan Penilaian Kesehatan Sungai Melalui Pemeriksaan Habitat Sungai dan Biotilik. Surabaya :Djitoe Percetakan Surabaya; 2011..

8. Peraturan Gubernur Sumsel No 16 Tahun 2005 Tentang Baku Mutu Air Sungai

9. OkidParamaAstirin, Ahmad DwiSetyawan, Marti Harini. Keragaman Plankton sebagai Indikator Kualitas Sungai di Kota Surakarta. Jurnal Biodiversitas. Volume 3 No. 2; 236-241. 2002. 
10. Siregar, Fithra. Keanekaragaman Ikan Sungai Kampar Inventarisasi dari Sungai Kampar Kanan. Journal of Environmental Scince. Volume 2 No. 4: 139-147. 2010.

11. Wijaya, Habib Krisna. Komunitas Perifiton dan Fitoplankton serta Parameter Fisika-Kimia Perairan sebagai Penentu Kualitas Air di Bagian Hulu Sungai Cisadane, Jawa Barat. Skripsi. Fakultas Perikanan dan Ilmu Kelautan. Institut Pertanian Bogor. 2009

12. Tyas, MustikaWahyuning dan Joko Widiyanto. Identifikasi Gastropoda di Sub DAS Anak Sungai Gandong Desa Kerik Takeran. Jurnal Florea Volume 2 No. 2, Nopember 2015 (5257). 2015.

13. Lebaa, Gladyes V, Roni Koneria, AdelfiaPapu. Keanekaragaman Serangga Air di Sungai Pajowa Kabupaten Minahasa, Sulawesi Utara. Jurnal MipaUnsrat Online 2 (2) 73-78. 2013.
14. Sugiharto. Dasar-Dasar Pengelolaan Air Limbah. Jakarta : Universitas Indonesia Press (UI-Press); 2008.

15. PP no 82 Tahun 2001

16. Muhajir, Mika Septiawan. Penurunan Limbah Cair BOD dan COD Pada Industri Tahu Menggunakan Tanaman Cattail dengan Sistem Constructed Wetland. [Skripsi]. Fakultas Matematika dan Ilmu Pengetahuan Alam Universitas Negeri Semarang; 2013.

17. Hendrawan, Diana. Kualitas Air Sungai dan SITU di DKI Jakarta. MAKARA. Volume 9 No. 1, April: 13-19. 2005.

18. Agustiningsih, Dyah, Setia Budi Sasongko, dan Sudarno. Analisis Kualitas Air dan Strategi Pengendalian Pencemaran Air Sungai Blukar Kabupaten Kendal. Jurnal PRESIPITASI. Volume 9 No.2 September 2012; (64-71). 2012 